\title{
17. HEAVY-MINERAL COMPOSITION OF TERTIARY SEDIMENTS AT DEEP SEA DRILLING PROJECT SITES 445 AND 446, NORTHEASTERN PHILIPPINE SEA
}

\author{
Yoshiaki Sato, Fuel Department, Geological Survey of Japan, Tokyo
}

\begin{abstract}
Heavy-mineral analyses were made for 39 samples, 27 from DSDP Site 445 and 12 from Site 446. About one-fourth of the samples were so loose that they were easily disaggregated in water. The amount of heavy residue and the magnetite content of the heavy fraction were very high, 0.2 to 44 per cent and (on the average) more than 20 per cent, respectively. Among the non-opaque heavy minerals, common hornblende ( 0 to $80 \%$ ) and augite (0 to $98 \%$ ) are most abundant. Pale-green and bluish-green amphiboles (around $10 \%$ ) and the epidote group (a few to $48 \%$ ) are next in abundance. Euhedral apatite and biotite and irregularly shaped chromite are not abundant, but are present throughout the sequence. Hacksaw structure is developed in pale-green amphibole and augite.

At Site 445 , a fair amount of chlorite and a few glauconite(?) grains are present from Core 445-81 downward. The content of common hornblende and opaque minerals also changes from Core 445-81 downward. A geological boundary may exist between Cores 445-77 and $445-81$.

Source rocks of the sediments at both sites were basaltic volcanic rocks (possibly alkali suite), schists, and ultramafic rocks.

The degree of lithification and amount of heavy residue, and the content of magnetite, non-opaque heavy minerals (excluding mafic minerals), and mafic minerals in the cores were compared with Eocene, Oligocene, and Miocene sandstones of southwest Japan. In many respects, the sediments at Sites 445 and 446 are quite different from those of southwest Japan. From the early Eocene to the early Miocene, the area of these sites belonged to a different geologic province than southwest Japan.
\end{abstract}

\section{INTRODUCTION}

In studying heavy minerals in Tertiary and Quaternary sediments of Japan, one of the main interests has been comparison of heavy-mineral compositions and provenance between Japan and other areas. To further pursue this, a study was made of heavy minerals in cores from Sites 445 and 446 in the Daito Ridge and the Daito Basin, south of Kyushu and east of Okinawa. The ages of the sediments range from early Eocene to early Miocene. The author and his colleagues have published many reports on sandstones of about the same ages in southwest Japan (Sato, 1961, 1964, 1969; Sato and Suzuki, 1977; Suzuki and Sato, 1978; Ohara, 1961; Ohara and Matsumoto, 1964).

The purpose of this study was to obtain data on heavy-mineral composition of the sediments at Sites 445 and 446 and to compare the results with data on sandstones in northwest Kyushu and Okinawa and Iriomote in the Nansei Islands (Figure 1).

\section{SAMPLES AND METHODS OF ANALYSIS}

Thirty-nine samples were analyzed, 27 from Site 445 and 12 from Site 446 (Holes 446 and 446A). The sample interval for Site 445 is about one from every core (about $9 \mathrm{~m}$ ), from Cores 445-66 to 445-91. The rest of the analyzed samples were taken at irregular intervals. The volume of each sample is about $10 \mathrm{~cm}^{3}$. The sediments are chalk, calcareous mudstone, and finely interbedded sandstone and siltstone with occasional rock fragments. The ages of the samples range from early Eocene to early Miocene.

The samples were gently crushed with an iron mortar and pestle to minimize the destruction of original features of the heavy-mineral grains. About one-fourth of the samples were so loose that they were easily disaggregated in water by hand or using a rubber pestle. (It is noteworthy that sediments as old as Eocene are so little consolidated at these sites.)

The material was then sieved through a screen with 0.25 -mm openings. The finer fraction (smaller than 0.06 


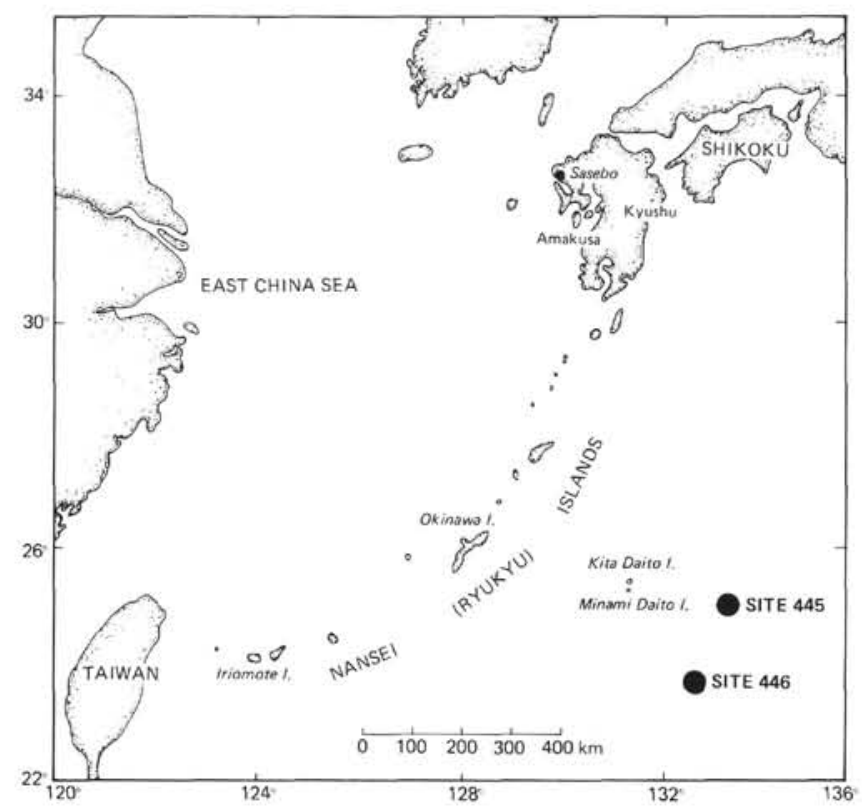

Figure 1. Location map of study area.

$\mathrm{mm}$, or silt and clay size) was decanted. About 2 to 3 grams of each dried sample was centrifuged for $5 \mathrm{~min}$ in tetrabromoethane (sp. gr. 2.9).

After washing with acetone, the heavy residue was weighed. Magnetite was removed by a bar magnet and weighed to obtain the amount. The weight per cent of heavy minerals in the samples and the weight per cent of magnetite and other heavy minerals in the heavy residue are shown in Table 1.

Part of the heavy residue was mounted on a glass slide with polysynthetic resin. More than 200 grains of non-opaque heavy minerals were identified and counted under a petrographic microscope. However, Sample $445-74-4,134-136 \mathrm{~cm}$ contained only 111 non-opaque grains; $445-88-2,32-34 \mathrm{~cm}$ contained 43 grains; and $445-91-1,50-51 \mathrm{~cm}$ contained 73 grains.

\section{HEAVY MINERALS}

Heavy minerals in the sediments of Site 445 generally constitute 1 to 8 per cent ( 20 samples). Two samples contain more than 8 per cent, and five samples less than 1 per cent. At Site 446, the amount is more than 5 per cent in nine of the 12 samples. Magnetite is also very abundant (more than 20\%) in most samples. These values are much higher than those for sandstones in southwest Japan.

\section{Grain Size}

The size of mafic mineral grains (amphiboles, pyroxenes, biotite) is variable; maximum length of these grains is commonly near $0.4 \mathrm{~mm}$ (Figures 2 and 3). A length of 0.20 to $0.15 \mathrm{~mm}$ is common. Other mineral grains, except sphene, are rather small. Their maximum length varies between 0.15 and $0.08 \mathrm{~mm}$, lengths of about $0.10 \mathrm{~mm}$ being common.

\section{Grain Shape}

Almost all the minerals are angular and have no trace of wear. They are euhedral, prismatic, or irregular in shape (Figures 4, 5, and 6). A few biotite grains are wellrounded (Figure 7). The cause of rounding is not clear.

Pale-green amphibole and augite have well-developed hacksaw terminations (Figures 8 and 9), indicating strong intrastratal solution.

\section{Sphene}

Long-prismatic, yellow, euhedral sphene with welldeveloped crystal faces occurs in Sample 446A-12-3, $70-71 \mathrm{~cm}$. Maximum length reaches $0.50 \mathrm{~mm}$, and a length of about $0.20 \mathrm{~mm}$ is common.

\section{EPMA Analysis}

Yuasa (pers. comm.) analyzed about 30 uncertain heavy mineral grains in the samples below with EPMA and confirmed the following minerals:

Sample 445-34-2, 74-76 cm

Bluish-green amphibole, actinolite, and picotite.

Sample 445-53-4, 98-100 cm Enstatite, diopside, picotite, actinolite, and hornblende.

Sample 446-38, CC, $30-35 \mathrm{~cm}$ Titaniferous augite $\left(\mathrm{TiO}_{2}\right.$ from 1.1 to $2.8 \%$ ), hornblende, hedenbergite, and aegirine-augite.

\section{HEAVY-MINERAL ZONES}

On the basis of heavy-mineral assemblages (Table 1), four groups of samples can be recognized at Site 445, and three groups at Site 446 (Table 2). However, because samples of groups 445-I, 445-II, 446-I, 446-II, and 446-III are sporadic, it is difficult to say whether the boundaries between 445 -I and 445 -II, between 445 -II and 445-III, between 446-I and 446-II, and between 446-II and 446-III have geological significance.

On the other hand, samples of groups 445 -III and 445-IV were taken at fairly regular intervals (one sample in each core, but some cores not represented). Thus, the change in mineralogy from 445-III to 445-IV (decrease in common hornblende and augite, appearance of chlorite and glauconite(?), increase in opaque minerals) is meaningful - geological conditions had changed during this period.

In this connection, it is of interest that the boundary between lithologic units V-A and V-B (Site 445 report, this volume) lies between Cores $445-81$ and 445-82, which is very close to the heavy-mineral boundary.

\section{POSSIBLE SOURCES OF HEAVY MINERALS}

The provenance of common hornblende, augite, magnetite, reddish-brown hornblende, biotite, and apa- 
TABLE 1

Percentage of Non-opaque Heavy Minerals, Heavy Residue, Magnetite, and Opaque Heavy Minerals, DSDP Sites 445 and 446

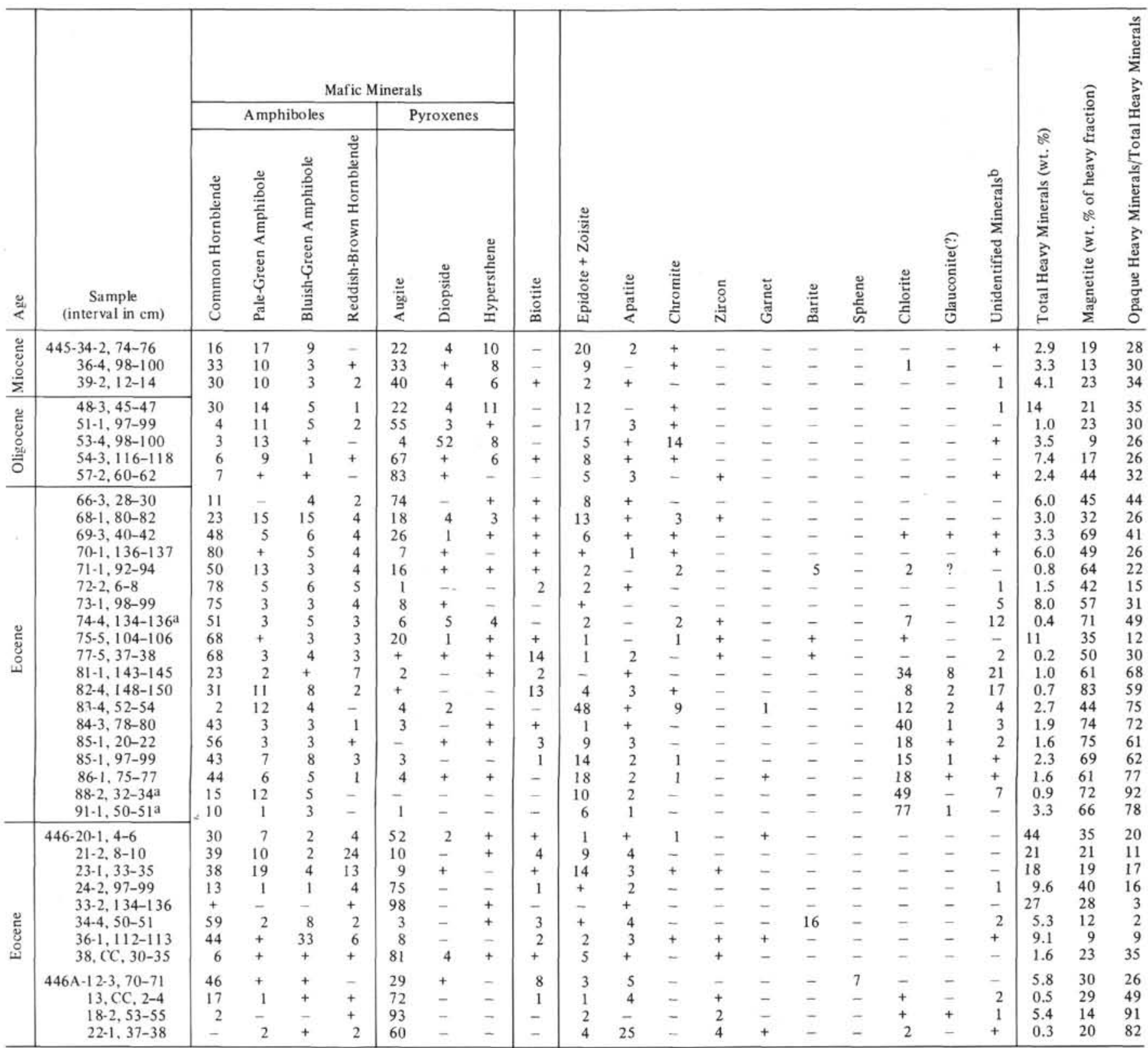

a Number of non-opaque heavy-mineral grains fewer than 200.

bincludes carbonates.

tite was volcanic rocks, as shown by their variable grain size and irregular shape. Rock fragments of altered basalt or trachyandesite are commonly found in a thin section of Sample 445-77-5, 45-46 cm. The presence of swallow-tail structure in plagioclase crystals, hyaloclastic structure in basalt fragments, and glass in the basalt are evidence of rapid cooling of a subaqueous flow. It seems possible that olivine was present at the time of emplacement, but has been lost during diagenesis.

The association of common hornblende, augite (especially titaniferous aưgite), and biotite - without hypersthene - indicates that the source rocks were basaltic volcanic rocks of the alkalic suite.

Epidote and pale-green and bluish-green amphiboles were derived from metamorphic rocks, probably schists. In Sample 445-34-2, 74-76 cm a grain of bluishgreen amphibole with an actinolite (pale-green) core was recognized by Yuasa (pers. comm.). According to Yuasa and Watanabe (1977), this kind of bluish-green amphibole commonly is found in the Abukuma metamorphic rocks in northeast Japan and in the dredged pebbles of hornblende schist on the Daito Ridge. Heavy minerals in the schist pebbles are elongated, bluish- 


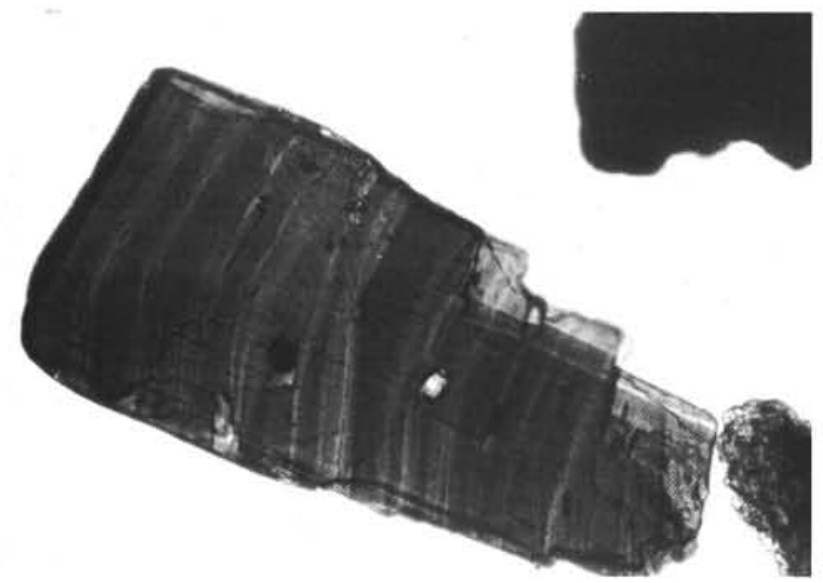

Figure 2. Large common-hornblende grain. Sample 445$69-3,40-42 \mathrm{~cm}$. Length $0.40 \mathrm{~mm}$.

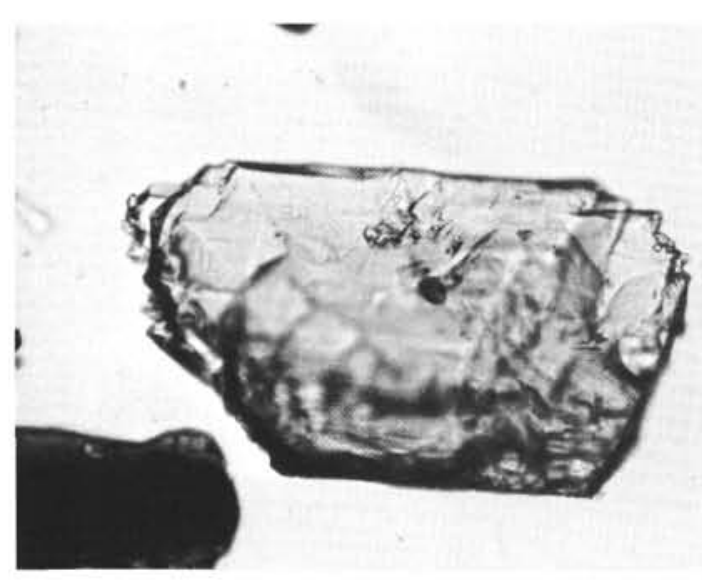

Figure 3. Large augite grain. Sample 445-75-5, 104-106 $\mathrm{cm}$. Length $0.38 \mathrm{~mm}$.

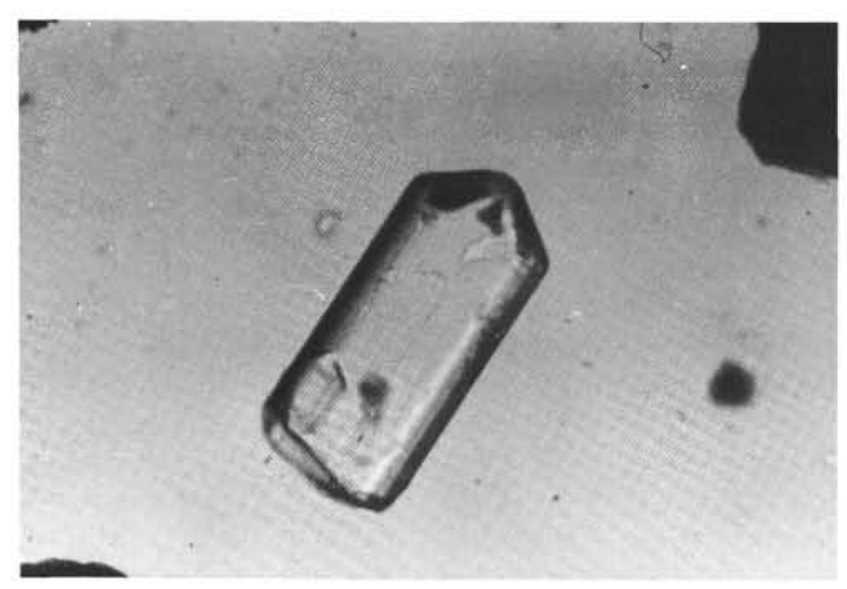

Figure 4. Euhedral apatite grain. Sample 445-84-3, 78$80 \mathrm{~cm}$. Length $0.22 \mathrm{~mm}$.

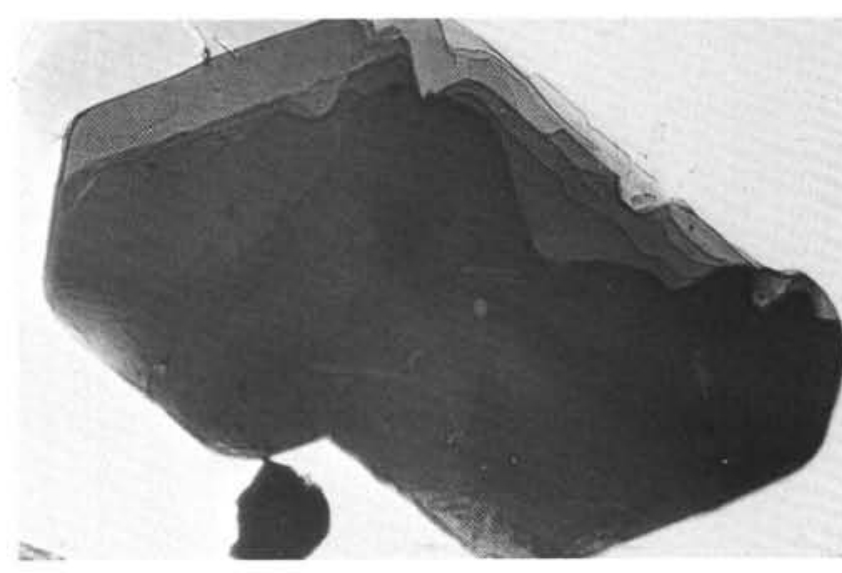

Figure 5. Euhedral biotite grain. Sample 445-72-2, 6-8 $\mathrm{cm}$. Greatest length $0.52 \mathrm{~mm}$.

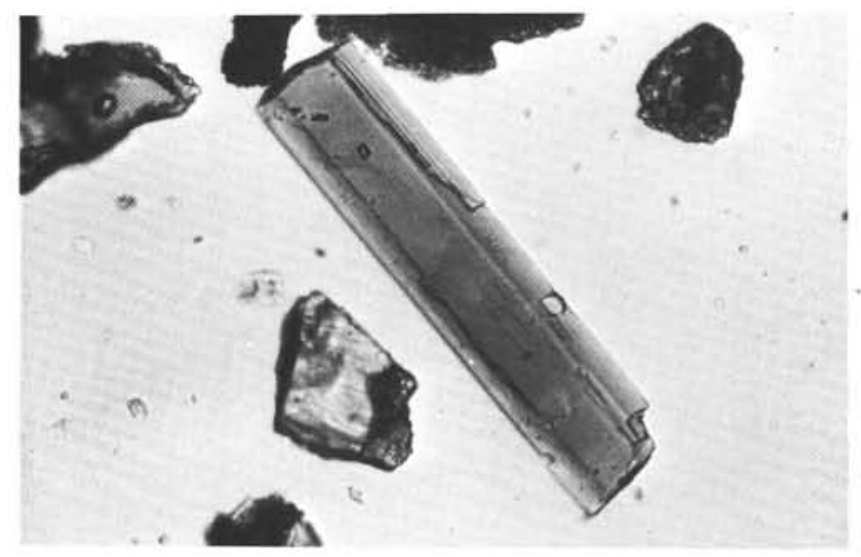

Figure 6. Prismatic common-hornblende grain. Sample $445-66-3,28-30 \mathrm{~cm}$. Length $0.34 \mathrm{~mm}$.

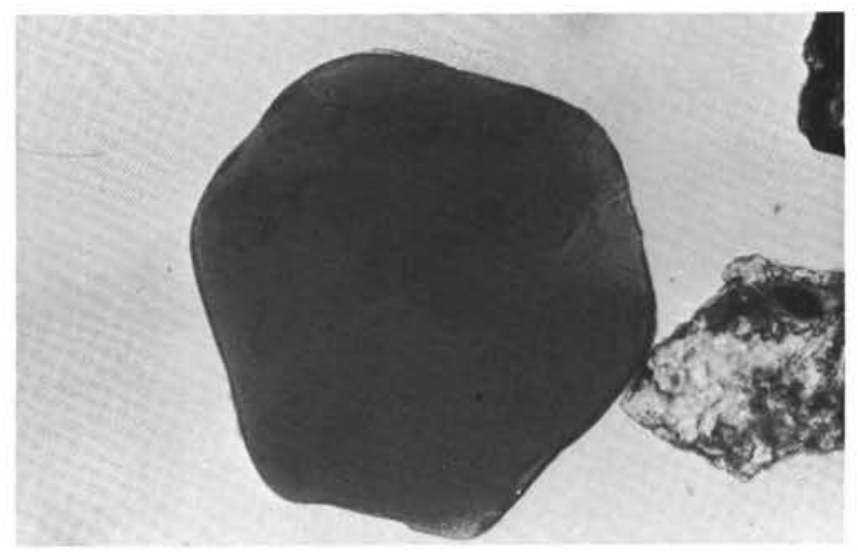

Figure 7. Rounded biotite grain. Sample 445-77-5, 37$38 \mathrm{~cm}$. Length $0.32 \mathrm{~mm}$. 


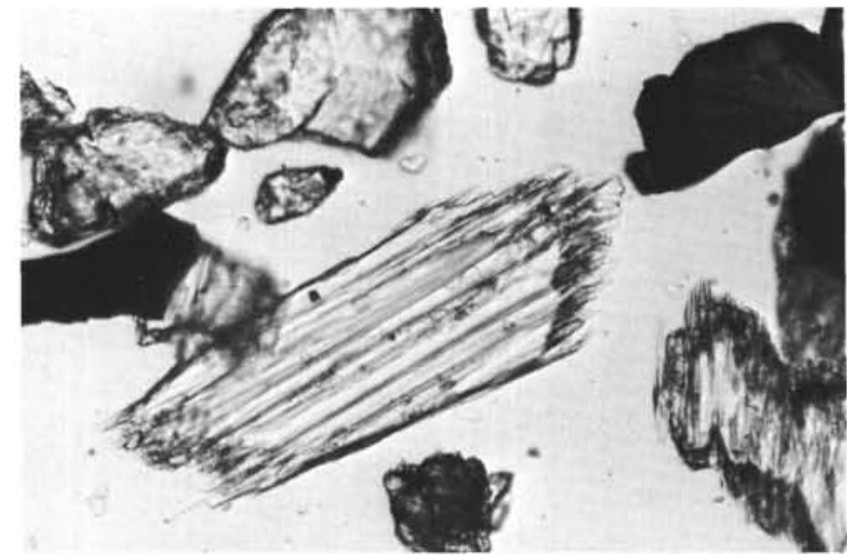

Figure 8. Colorless amphibole with hacksaw termination. Sample 445-53-4, 98-100 cm. Length $0.36 \mathrm{~mm}$.

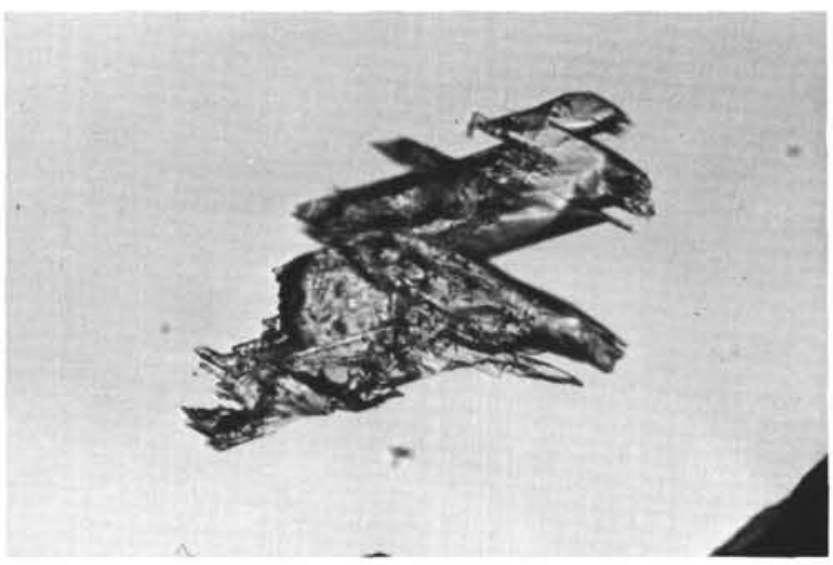

Figure 9. Augite with well-developed hacksaw termination. Sample 445-70-1, 136-137 cm. Greatest length $0.34 \mathrm{~mm}$

TABLE 2

Heavy Mineral Groups and Their Average Composition, DSDP Sites 445 and 446

\begin{tabular}{|c|c|c|c|c|c|c|}
\hline Site & Group & $\begin{array}{c}\text { Samples } \\
\text { (see Table 1) }\end{array}$ & $\begin{array}{l}\text { Common } \\
\text { Horn- } \\
\text { blende }\end{array}$ & Augite & $\begin{array}{l}\text { Hyper- } \\
\text { sthene }\end{array}$ & Opaque \\
\hline \multirow[t]{4}{*}{445} & 1 & $\begin{array}{l}445-34-2,74-76 \\
\text { to } 445-48-3,45-47\end{array}$ & 27 & 27 & 9 & 32 \\
\hline & II & $\begin{array}{l}445-51-1,97-99 \\
\text { to } 445-66-3,28-30\end{array}$ & 6 & 56 & - & 32 \\
\hline & III & $\begin{array}{l}445-68-1,80-82 \\
\text { to } 445-77-5,37-38\end{array}$ & 60 & 11 & - & 28 \\
\hline & IVa & $\begin{array}{l}445-81-1,143-145 \\
\text { to } 445-81-1,50-51\end{array}$ & 34 & 2 & - & 72 \\
\hline \multirow[t]{3}{*}{446} & 1 & $\begin{array}{l}446-20-1,4-6 \\
\text { to } 446-36-1,112-113\end{array}$ & 32 & 36 & - & 11 \\
\hline & 11 & $\begin{array}{l}446-38, C C, 30-35 \\
\text { to } 446 \mathrm{~A}-13, \mathrm{CC}, 2-4\end{array}$ & 23 & 61 & - & 37 \\
\hline & III & $\begin{array}{l}446 \mathrm{~A}-18-2,53-55 \\
\text { to } 446 \mathrm{~A}-22-1,37-38\end{array}$ & 1 & 77 & - & 87 \\
\hline
\end{tabular}

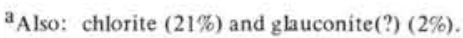

green amphibole, actinolite, epidote, ilmenite, and sphene. The dredged pebbles, other than hornblende schist, are serpentinite and conglomerate containing serpentinite, tremolite schist, and basaltic rock. These facts suggest that part of the material at these sites was derived from schist. Picotite, and probably diopside and enstatite, came from ultramafic rocks.

\section{COMPARISON OF HEAVY-MINERAL ASSEMBLAGES AT THE DSDP SITES AND IN SOUTHWEST JAPAN}

The heavy-mineral composition of the sediments at the DSDP sites was compared to that of sandstones of about the same ages in southwest Japan. Heavy-mineral data in southwest Japan pertain to sandstones in several coalfields in northwest Kyushu (Eocene, Oligocene, and Miocene), Okinawa Island (Kayo Formation, Eocene), and Iriomote Island (Yaeyama Group, early Miocene). Nummulites amakusensis has been found in the lower part of the lower Eocene in the Amakusa coalfield, northwest Kyushu (Mizuno, 1977), and Nummulites boninensis has been found in the Kayo Formation, Okinawa Island (Konishi et al., 1973).

Although these areas are fairly distant, and the sedimentary environments qre somewhat different, the heavy-mineral compositions of the sandstones are very similar. In the following discussion, these areas are collectively called "southwest Japan" for convenience.

Marine geosynclinal sequences ranging from Paleogene to lower Miocene are distributed in southeast Kyushu, but because no heavy-mineral study has been done yet, they are excluded.

\section{Lithification}

The sandstones of southwest Japan have been highly lithified, and it took time to crush them into sand-sized grains.

However, about one-fourth of the samples from Sites 445 and 446 , in spite of their geologic age, were easily disaggregated in water by hand or a rubber pestle. The rest of the samples also could be crushed easily in an iron mortar and pestle without destroying the delicate hacksaw structure of amphibole and augite.

\section{Total Heavy Minerals and Magnetite}

The quantity of heavy residue in the sandstones of southwest Japan is generally less than 1 per cent. Values less than 0.1 per cent are common. The magnetite content is almost negligible (Table 3). However, 22 of 27 samples from Site 445 and 10 of 12 samples from Site 446 contain more than 1 per cent heavy minerals. The magnetite content is also very high, ranging from 9 to 83 per cent. Abundant heavy residue and magnetite are present in Neogene and Quaternary pyroclastic sediments in Japan.

\section{Non-Opaque Heavy Minerals (excluding mafic minerals)}

Zircon, garnet, tourmaline, and, locally, epidote are the four major non-opaque heavy minerals in the sandstones of southwest Japan (Table 3). These minerals represent more than 80 per cent of the non-opaque heavy minerals in most of the sandstones (Sato, 1969). Only the ratios between minerals vary from formation to formation or from place to place. Sato (1969) in- 
TABLE 3

Average Heavy-Mineral Content of Sandstones of Southwest Japan (\%)

\begin{tabular}{|c|c|c|c|c|c|c|c|c|}
\hline Area and Stratigraphic Unit & $\begin{array}{l}\text { E } \\
\text { ్ㅗ }\end{array}$ & 总 & 总 & 음 & $\frac{\text { L }}{\stackrel{c}{c}}$ & 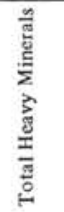 & 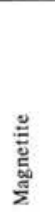 & 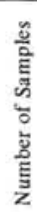 \\
\hline \multicolumn{9}{|l|}{ Northwest Kyushu } \\
\hline $\begin{array}{l}\text { Nakazato Formation (Miocene) } \\
\text { Sase bo coalfield }\end{array}$ & 17 & 76 & 3 & 0 & 4 & 0.3 & 0 & 22 \\
\hline $\begin{array}{l}\text { Maze Formation (Oligocene) } \\
\text { Nishisonogi Peninsula }\end{array}$ & 6 & 68 & 21 & 2 & 3 & 1.2 & n.d. & 31 \\
\hline $\begin{array}{l}\text { Yoshinotani Formation (Oligocene) } \\
\text { Karatsu coalfield }\end{array}$ & 61 & 16 & 16 & 0 & 7 & 0.07 & n.d. & 12 \\
\hline $\begin{array}{l}\text { Shimoshima Group (Eocene) } \\
\text { Amakusa coalfield }\end{array}$ & 62 & 5 & 12 & + & 21 & 0.1 & n.d. & 15 \\
\hline \multicolumn{9}{|l|}{ Nansei Islands } \\
\hline $\begin{array}{l}\text { Yaeyama Group (Miocene)e } \\
\text { Iriomote Island }\end{array}$ & 37 & 8 & 33 & 0 & 22 & 0.6 & n.d. & 4 \\
\hline Kayo Formation (Eocene $)^{f}$ & 87 & 0 & 10 & 0 & 3 & 0.06 & 0 & 4 \\
\hline
\end{tabular}

a Suzuki and Sato (1978)

b,cSato (1964)

dSato (1961)

Ohara and Matsumoto (1964)

fSato and Suzuki (1977)

ferred that the source rocks of these sandstones were granitic or arkosic, with some metamorphic rocks (schists).

However, epidote is the only mineral commonly seen throughout the sequences of Sites 445 and 446. Zircon and garnet occur in trace amounts (few grains only), and tourmaline is absent at both sites.

\section{Mafic Minerals}

The term "mafic minerals" here includes biotite, amphiboles, and pyroxenes.

Mafic minerals are negligible in the sandstones of southwest Japan. Like magnetite, mafic minerals are an important constituent in younger (Neogene and Quaternary), pyroclastic sediments. In these sediments, hypersthene is most common. Generally, the most frequent associations of mafic minerals are common hornblende + hypersthene, hypersthene + augite, and common hornblende + hypersthene + augite. These associations are characteristic of calc-alkalic rocks.

Whereas hypersthene is uncommon at the Leg 58 sites, the dominant mafic minerals are amphiboles and augite. As noted earlier the association of common hornblende, augite (especially titaniferous augite), biotite, and basaltic rock fragments is suggestive of the alkalic suite, rather than calc-alkalic suite.

\section{CONCLUSIONS}

1. Heavy mineral analyses were made on 39 samples of Eocene, Oligocene, and Miocene sediments of DSDP Sites 445 and 446. About one-fourth of the samples were easily disaggregated in water; lithification of these old sediments is not advanced.

2. The amount of heavy residue and the magnetite content of the heavy residue are very high (on the average, more than $1 \%$ and more than $20 \%$, respective- ly). Among non-opaque heavy minerals, common hornblende ( 0 to $80 \%)$ and augite ( 0 to $98 \%)$ are most abundant. Pale-green and bluish-green amphiboles (around $10 \%$ ) and the epidote group (a few to $48 \%$ ) are next. Euhedral apatite and biotite and irregularly shaped chromite are rare or uncommon, but occur throughout the sequence. Hacksaw structure is developed in palegreen amphibole and augite. Zircon and garnet are rare, and tourmaline is absent.

3. At Site 445, a fair amount of chlorite and a few glauconite(?) grains are present from Core 445-81 downward. The content of common hornblende, augite, and opaque minerals also changes from Core $445-81$ downward. A geological boundary may exist between Cores 445-77 and 445-81. This boundary is close to that between lithologic units V-A and V-B.

4. Source rocks of the sediments at both sites were basaltic volcanic rocks (possibly alkalic suite), schists, and ultramafic rocks.

5. Degree of lithification, amount of heavy residue, and contents of magnetite, non-opaque heavy minerals other than mafic minerals, and mafic minerals in the cores were compared with sandstones of similar ages in southwest Japan. The heavy minerals of the sediments at DSDP Sites 445 and 446 are, in every respect, different from those of sandstones of southwest Japan. From the Eocene to the early Miocene, the area of the DSDP sites belonged to a different geologic province than southwest Japan.

\section{ACKNOWLEDGMENTS}

I would like to express my sincere thanks to $\mathrm{K}$. Ono of the Geological Survey of Japan for his helpful criticism. I am grateful to Dr. D. J. Lyons, consultant of Technology Research Center, Japan Petroleum Corporation, who kindly read the manuscript. Thanks are also due to M. Yuasa of the Geological Survey of Japan for EPMA analysis of heavy-mineral grains and for his valuable suggestions.

\section{REFERENCES}

Konishi, K., Ishibashi, T., and Tsuruyama, K., 1973. Find of Nummulites and orthoquartzitic pebbles from Eocene turbidite in Shimajiri Belt, Okinawa. Sci. Rept. Kanazawa Univ., 18 (1), 43-53.

Mizuno, A., 1977. Paleogene System. In Tanaka, K., and Nozawa, T. (Eds.), Geology and Mineral Resources of Japan: Tokyo (Geol. Survey of Japan), pp. 214-232.

Ohara, J., 1961. Heavy mineral associations in the Paleogene Systems of some coal fields, North Kyushu, Japan. Memoirs Faculty of Sci., Kyushu Univ., Ser. D, Geol., 11, 381418.

Ohara, J. and Matsumoto, Y., 1964. Heavy minerals in the sandstones of the Yaeyama Group in the Iriomote-Jima, the Yaeyama Islands (Yaeyama-gunto). Rept. Committee on Foreign Scientific Res., Kyushu Univ., 2, 47-56.

1961. Heavy minerals in the Paleogene formations of Higashi Nagasaki-machi and Amakusa Shimo-shima Island, Middle Kyushu. Bull. Geol. Survey of Japan, 12, 697-709.

1964. Heavy minerals in the Paleogene formations of the Karatsu coal field and the Nishisonogi Peninsula, 
Northwest Kyushu, Japan. Bull. Geol. Survey of Japan, $15,36-58$.

1969. Geological significance of zircon-garnettourmaline ratio of the Paleogene sandstones of northwestern Kyushu, Japan. Rept. 235, Geol. Survey of Japan.

Sato, Y. and Suzuki, T., 1977. Heavy minerals in the Neogene Shimajiri Group, Okinawa Island. Bull. Geol. Survey of Japan, 28, 497-502.
Suzuki, T. and Sato, Y., 1978. A vertical change of heavy mineral assemblage in the core of a borehole in Sasebo Coalfield, Kyushu, Japan. Bull. Geol. Survey of Japan, 29, 807-816.

Yuasa, M. and Watanabe, T., 1977. Pre-Cenozoic metamorphic rocks from the Daito Ridge in the northern Philippine Sea. J. Japanese Assoc. Mineralogists, Petrologists and Economic Geologists, 72, 241-251. 